\title{
The use of task-based language teaching method to teach terms and phrases for those learning Turkish as a second language and sample activities
}

\author{
Bahattin Şimşek $^{\mathrm{a} *}$ (iD), Sıddık Bakir ${ }^{\mathrm{b}}$ \\ ${ }^{a}$ Ataturk University, Yakutiye, Erzurum/25010, Turkey \\ ${ }^{b}$ Ataturk University, Yakutiye, Erzurum/25010, Turkey

\section{APA Citation:} \\ Şimşek, B., \& Bakır, S. (2019). The use of task-based language teaching method to teach terms and phrases for those learning Turkish as a \\ second language and sample activities. Journal of Language and Linguistic Studies, 15(2), 719-738. \\ Submission Date: $17 / 05 / 2019$ \\ Acceptance Date: 25/06/2019
}

\begin{abstract}
Human beings, since they first met different languages and cultures, have had an urge to learn those languages and cultures. In modern societies, this urge has currently turned into a necessity. As a result of this necessity, the supply-demand balance has changed and the rate of language learning and acquiring new cultures have increased parallel to the rising world population. All these developments required the language teaching and learning process to be implemented as a scientific discipline. A plethora of different methods have emerged and shaped on the basis of scientific data. One of these methods is "Task-based Language Teaching (TBLT)". This method was introduced in the last quarter of 20th century and has still been widely used in language teaching today.

In this study, we tried to teach new terms and phrases to $\mathrm{C} 1$ level learners learning Turkish as a second language with task-centered activities formed in compliance with the principles of task-based language teaching method. Terms and phrases are vital for $\mathrm{C} 1$ level learners to be an independent performer of the language in four basic skills of language.

Two discrete sections form up this study. In the first section, literature review and general information about taskbased language teaching method are introduced. In the latter, there are seven sample activities formed with regard to the instructional design of task-based language teaching method. In these activities, we tried to teach terms and phrases through various tasks.
\end{abstract}

(C) 2019 JLLS and the Authors - Published by JLLS.

Keywords: teaching Turkish as a foreign language; task-based language teaching; terms; phrases; activity design

\section{Introduction}

Learning and teaching a foreign language have been an on-going process for thousands of years. It is a phenomenon which is scientifically and practically investigated and practiced today. There are plenty of different methods and applications in foreign language education in compliance with the learning needs of the people. These methods aim to make the learning process more permanent and more effective in a shorter span of time in the developing world. In this way, a high efficiency is to be obtained from a short time period, saving time and cash. All of these circumstances lead to the development of

\footnotetext{
${ }^{*}$ Corresponding author. Tel.: +904422314661
}

E-mail address: b.simsek@atauni.edu.tr 
new approaches, methods and techniques to answer the question of how to teach people a language other than their native language. These methods have continued and will continue their development by originating or utilizing from scientific backgrounds and other sciences. One of these methods is "taskbased language teaching" which is considered within the communicative language teaching approach (Richards \& Rodgers, 1999; Nunan, 1991, 2001; Ortega, 2015; Willis, 2007;).

\subsection{Literature review / Theoretical background}

\subsubsection{Task-Based Language Teaching}

In the Turkish Dictionary by Turkish Language Association (TLA), "task" is described as "1. Work of an object or someone, an action which is expected from one's self. 2. Performance capacity." In the area of educational sciences, task is defined as the actions and procedures one can undertake within the scope of the workload and in the course of production in order to achieve the organizational objectives (Güneş, 2015, p. 179). Applied in the area of language teaching, task is defined as the activities which ensure the progress of the learners within the process of language learning.

Task-based learning was developed by N. Prabhu in India. According to Prabhu, if the learners improve their language skills in a task-oriented way, language learning will be more effective (Prabhu, 1987). With this in mind, Prabhu put forward the idea that task-based learning can be widely used in education. This learning design was later systematized and expanded by Janes Willis.

What Prabhu considers as "task" is that the learners come to a conclusion with the data provided in a thinking process in which the teacher controls and shows the required activities for the learners to arrange. In other words, "task" is all the areas of communication that include the use of the target language in all kinds of events for the communicative purpose, from solving a puzzle to booking at the airport (Doğan, 2012, p. 381).

"Willis (1996) states that the task-based language teaching is more enhanced and logical than the communicative language teaching. Tasks performed in real communication are essential elements of language learning. Significant tasks both encourage and support learning in the process of education." (Richards \& Rodgers, 2002, p. 223) Considered among foreign language teaching methods, the taskbased language teaching is a method that enables students to develop their language skills interacting with their environment through the tasks given to them and allows the learners to complete the language proficiency by making an effective use of the four skills of language within the same task process. According to Willis (1996), "task" is the keyword of this method. In task-based language teaching, attention is paid to presenting the language in a meaningful context as in everyday life. In this method, language is regarded as a means rather than an end for communication. (as cited in Yayl1, 2004).

Richards and Rodgers, on the other hand, define task as an objective or an activity performed using the language. There is a common belief that the tasks are meaningful activities and everyday language is transferred to the classroom environment. There is also a compromise that the tasks are communicative activities (Yorulmaz, 2009, p. 26).

In the definition of "task", the learners' activities performed for the purpose of target language communication are included. Tasks are activities which are independent; require comprehension, production, alteration and interaction in the source language; and prioritize the meaning rather than form itself (Yorulmaz, 2009, p. 26). Teachers play an important role in the selection of tasks requiring research and interpretation. The selected activities should be qualified as motivating and encourage the learners' abilities such as research and interpretation. Furthermore, targets should be set for the learners within the task and with these targets, the aim should be that the learners reach a conclusion.

Task-based language teaching provides important opportunities in that it encourages the learners to use four basic skills of language within the same activity. In the process of the language development, 
it is acknowledged that a student should succeed in these four basic language skills so as to learn that language proficiently.

In the task-based language teaching, the learners acquaint themselves with the vocabulary requisite for the task and use them afterwards as well, thus learning the vocabulary efficiently, which is the basis of language learning. By emphasizing that words should not be taught in a mere way as in the dictionary, the teachers of foreign languages state that they should be taught in a way that will be confronted in daily life such as phrases, sentences or common expressions, which makes learning easier (Yayl1, 2004, p. 18).

At its most basic, task-based instruction rejects the notion that knowledge can be learned independently of its application and embraces instead the value of learning by doing, or "experiential learning". In Dewey's terms, principal elements around which instruction should be built are "activities worthwhile for their own sake" (p. 87), and it is by engaging learners in doing valued activities that relevant declarative and procedural knowledge is developed, learners are motivated to engage with instructional content, and learners develop deep linkages between what they learn and how that learning can be put to use beyond the classroom.(Norris, 2009, p.578-579)

\subsubsection{The Constitutive Elements of Task-Based Language Teaching}

The elements of the method are to be evaluated within the framework of the approach, design and implementation process determined by Richards and Rodgers.

\subsubsection{The Approach}

According to Yayl1, the characteristics of task-based language teaching in terms of learning theory are:

"1. In addition to Krashen's "input" assumption, Swain (1985) emphasized that the term "output" is also important. According to Swain, the output in language acquisition plays an important role as much as the input does. Tasks empower processes such as reconciliation, regulation, and re-expression, which are invaluable for language acquisition.

2. Tasks also play an important role in student motivation (Willis, 1996). Because tasks enable the learners to use real-life language, consist of physical activity, ease the association and cooperation. They also allow the learners to project their experiences and encourage them to establish different ways of communication. All these attributes play an essential role in the motivation of the learners.

3. Another positive aspect of the tasks is that they can be edited in different ways to teach some of the features of language. The fact that tasks are too easy or difficult can cause problems in terms of student attention and fluency-accuracy affinity. Therefore, the difficulty degree of tasks can be rearranged in order to enable the learners to develop in both fluency and accuracy." (Yayl1, 2004, p. 19)

According to Norris, the positive aspects of TBLT are as follows:

"Tasks provided motivating communication activities that bore some relevance to language use beyond the classroom. Tasks also had the advantage of offering learners some reason for communicating, beyond practicing to do so, in that they came replete with actual outcomes, criteria for success or failure, even tangible results (getting what you ordered at the restaurant, winning the debate, etc.). In the classroom, tasks enabled teachers and learners to see language development as it unfolded in communication trial and error, thereby establishing a linkage between functions, the language forms that realized them, and the meaning-bearing uses to which they were put." (Norris, 2009, p. 580)

\subsubsection{Pattern}

The sub-categories of the pattern are goals, curriculum, types of teaching and learning activities, roles of learner, teacher and the teaching materials. 
Task-based language teaching determines the primary objectives in accordance with the needs of the students. That is to say, at the beginning of the curriculum creation process, what the learners want to learn and what they are deficient in are defined, and the curriculum is created with the learners' participation (Yayl1, 2004, p. 20).

The learning and teaching activities to be carried out in the courses have been a matter of debate upon the types of tasks in general. The task types proposed by task-based language teaching curriculum intrinsically constitute the essence of in-class activity.

According to Yayl, in the task-based teaching, the roles of the students are as follows:

"1. First of all, students are group members; because students perform tasks in groups.

2. Considering the role of the group member, tasks should be developed in a way that will enable the learners to observe how the language is used in communication. While working in the group, learners also contribute to the linguistic development of their friends by indirectly modeling their use of language. In other words, another role of the students is to create a model for other students.

3. Students also act as entrepreneurs and innovators who take risks in the group communication environment. Reproducing some of the statements, using non-linguistic communication, predicting through context, explaining, asking questions and consulting others are also the learner roles to be evaluated within the framework of this item.

The roles of the teachers are as follows:

1. The main role of teachers is to select, adapt and prepare the tasks apart from being a communicative teacher.

2. The teacher is the person who prepares the students for the task. Presentation of the subject, explanations, helping learners to learn how to complete the task and giving tips about the task is among these preparation activities.

3. Learners are required to be aware of new structures by hearing or seeing them while performing their tasks. The teacher is the one who raises awareness in the classroom. The teacher does not teach the new structure before the task but draws the attention of the learners to the new structures and structuremeaning relation in the course of the task.

4. The teacher watches the efforts of the learners from a certain distance and does not correct them during the task stage, which liberates the learners in the use of language. To encourage the learners in risk-taking, the teacher states that doing wrong is better than doing nothing. If learners are convinced that their mistakes are a natural consequence of language learning and adopt a positive attitude to the mistakes, it will be easier to improve their language experience. If the intended message is received during the task, the learner is considered accomplished. However, if the learner remains silent in this process, the probability of learning will decrease." (Yayl1, 2004, p. 21)

\subsubsection{Task Types}

Besides the textbooks prepared in accordance with the principles of task-based language teaching, the tasks prepared by the teacher are also used as teaching materials. Authentic tools support tasks. Objects that may contain tasks from real life can be used as teaching materials.

Task types are classified by Pica, Kanagy and Falodun, Nunan, Willis as in the table below. 
Table 1. Task types

\begin{tabular}{ll}
\hline Task Designer & Task Types \\
\hline & 1. Jig-saw tasks \\
Pica, Kanagy ve Falodun (1993) & 2. Information-gap tasks \\
& 3. Tasks that involve problem-solving \\
& 4. Tasks that involve decision-making \\
& 1. Real-life tasks \\
2. Experimental training tasks & 3. Tasks that activate training \\
& 1.Information-listing tasks \\
2.Tasks that sort and classify information & 3. Tasks that compare information \\
4. Problem-solving tasks & 5. Personal experience-sharing tasks \\
Willis (1996) & 6. Project and production tasks
\end{tabular}

In task-based language teaching, tasks are comprised of three stages and the learners are knowledgeable about what these stages are. They act in accordance with this.

Pre-task

Introduction to the subject and task: The teacher selects the subject with the learners, underlines the useful words and expressions and helps them grasp the task instructions and make the necessary preparations. The learners can listen to a tape-recording of a similar task.

Cycle of task

Task: The learners perform the task in pairs or small groups. The teacher observes them at a certain distance.

Plan: The learners prepare to present their task to the whole class. They make the presentation ready to demonstrate how they have fulfilled the task and what they have come up with.

Presentation: Some groups make presentations to the class or change the written presentations and make comparisons.

Focusing on the Language

Review: The learners review the texts or the characteristics of the listening dialogues and discuss them.

Applying the task: The teacher organizes the implementation of new words or expressions.

In task-based language teaching, the task processes are formed as above. Tasks are designed in such a way that the teacher and the learners interactively communicate with one another, learning takes place through the communication and cooperation within the group and the post-task feedback is accordingly anticipated.

\subsection{The Purpose of the Research}

The purpose of this study is to design sample activities with the intention of teaching expressions such as idioms, proverbs and also terms in Turkish using task-based teaching method with those who learn Turkish as a second language and to test the applicability of these activities by performing them with the learners. 


\section{Method}

\subsection{Research Design}

This study has a qualitative model. Furthermore, in this study, descriptive method was used and the activities were designed regarding the following pedagogical principles and practices developed by Nunan in the task-based language teaching method:

1. Need-oriented approach to content selection.

2. Emphasis on communicating through interaction in the target language.

3. Having the learners focus not only on the language, but the learning process as well.

4. Increasing the personal experience of the students as a significant contributor to classroom learning.

5. Reconciling the language used in and outside the classroom (Nunan, 2004).

In addition, the task processes proposed by Willis (1996) were also considered in this study. Task, planning and the presentation stages, which Willis (1996) included in the task cycle, are the stages of task activities designed for the learners.

Since the descriptive method was used in the study, the sample activities were comprised of the activity designs, in which task-based language teaching was applied, aiming to improve four basic language skills.

\subsection{Population and Sample}

The population of the study is all the learners of Turkish as a foreign language in C1 level according to the European Language Portfolio.

The sample is 12 students who learn Turkish at $\mathrm{C} 1$ level according to the European Language Portfolio, in Atatürk University Language Teaching and Education Research and Application Center. Random selection method was employed in the sample selection. In the selection of the sample and the design of the activities, the learning outcomes in C1 level in European Language Portfolio were taken into account.

The reason why the aforementioned level was chosen is that in $\mathrm{C} 1$ level, the terms and expressions are taught in the uttermost and the most competent way and the learner reaches the proficiency level of a native speaker of that language when the learning outcomes are considered.

\subsection{The Process of the Activity Design}

The activities for task-based language teaching method were designed and implemented with participant learners in a process of 7 weeks, each of which included one activity. During the implementation of the activities, a Facebook page called "Türkçe Öğreniyoruz" (We are learning Turkish) was created in order that the learners could maintain the communication and interaction among themselves as well as developing the activities interactively. They were also asked to share things in the group.

Designed to teach terms and expressions, these activities were created in accordance with the learners' interests. The contribution of activities on new vocabulary teaching were evaluated with the practices done before, during and after the activity, and the weaknesses were tried to be overcome in line with the views of learners and teachers. 
Moreover, participants were informed about what task-based language teaching and vocabulary were, and what methods they would use to enrich their vocabulary, and also the method of task-based language teaching was introduced. In the end, the applicability as well as the practicality of the activities were tried to be found out.

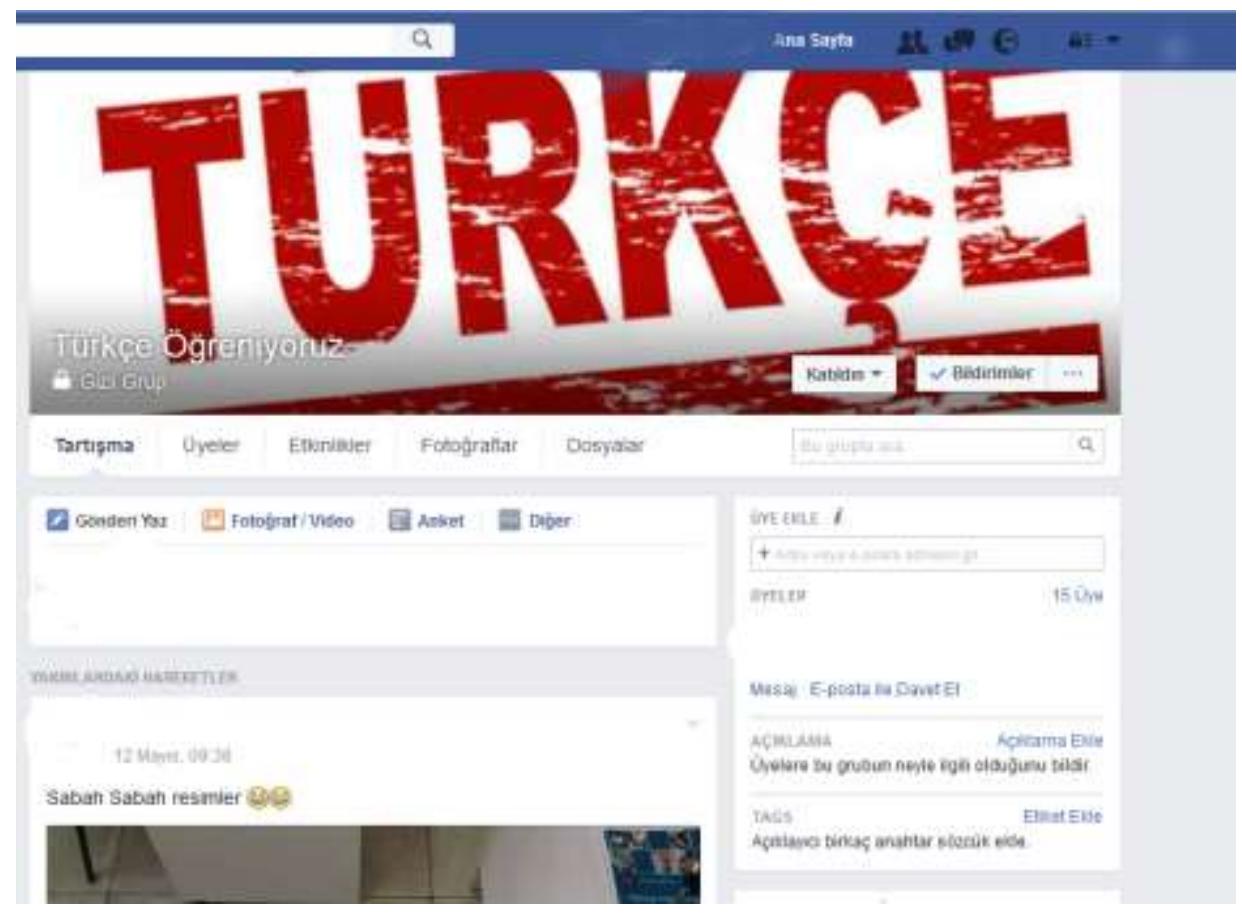

Illustration 1. Screenshot of the Facebook page where students could share about tasks

\section{Sample Activity Designs}

\subsection{Term Cloud Activity On the Learners' Fields of Education}

The purpose of this activity is to reveal how much the foreign learners of Turkish are familiar with the terms in the fields they will continue their higher education, to have them share with the other group members in the classroom and over the internet, to enable them to learn different and new terms.

Materials to be used in this activity: A plain white paper of A3 size on which students' areas of study (health, science, social, etc.) are written in a speech bubble or text box and a sufficient amount of selfadhesive paper (see in illus. 2)

In this activity, the learners will stick the adhesive papers, on which they have written the terms related to their fields, on the white paper, which is also called "idea tray". Before starting this task, the teacher should determine the areas where the learners in the classroom will study.

\subsubsection{Pre-task Stage}

The allocated span of time for the activity should be 2 to 10 minutes. Before distributing the necessary materials inside the classroom, the teacher should ask in which departments the learners are to continue their studies after Turkish education. The learners should be grouped in accordance with their answers. In the event that there are many learners from different fields of study, amalgamations could be made while splitting them into groups such as Physical Sciences, Social Sciences or Health Sciences. The teacher can tell the grouped learners to remember the terms related to their field in order 
to promote the task they will perform. In the meantime, the blank idea trays (sheet size:A3), on which the activities are to be made, should be distributed to the grouped learners. Following the distribution, the instructions about the task should be given. In this process, the teacher should start the task after explaining how to do the task and its duration.

\subsubsection{Task Cycle Stage}

The teacher should not intervene but relinquish the learners in the activity process. The teacher should walk among the students as an observer and intervene merely in the problems that the group members cannot solve. Meanwhile, the learners are both expected to write the meanings of the terms down in tandem and besides acquaint themselves with the meaning of the terms itself.

\subsubsection{Presentation Stage}

In this stage, the learners who have completed the task are asked to share their idea trays with the other groups. Each group should ask the learners in the other groups to guess the meaning of the terms in the new idea tray. The terms that cannot be predicted should be explained by the selected spokesperson of the group having created the idea tray. In this way, students will improve their ability to explain, exemplify a term or concept and build a mutual communication among themselves, which will also serve to the purpose of teaching Turkish terms. Finally, students should be asked to share these idea trays on their online Facebook page, using the appropriate programs in the computer environment.

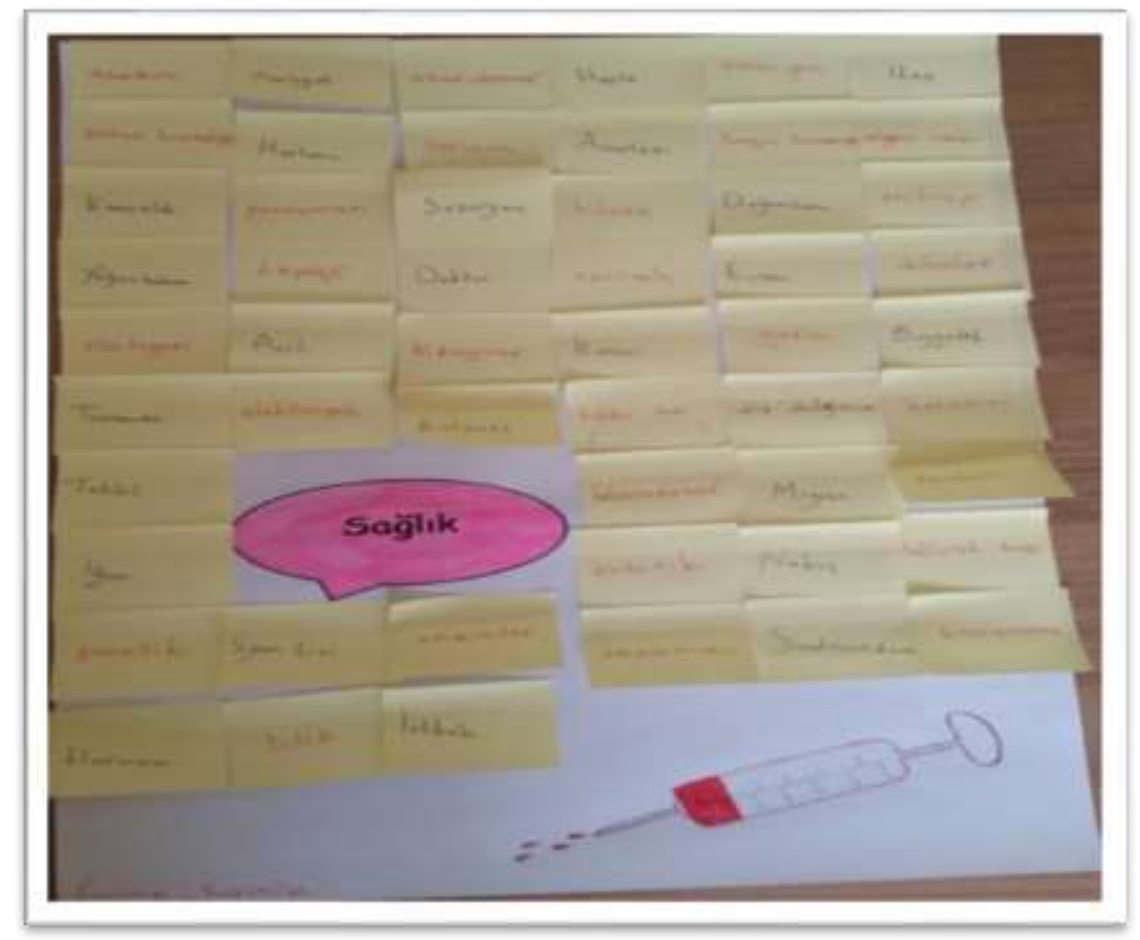

Illustration 2. An image of an idea tray 


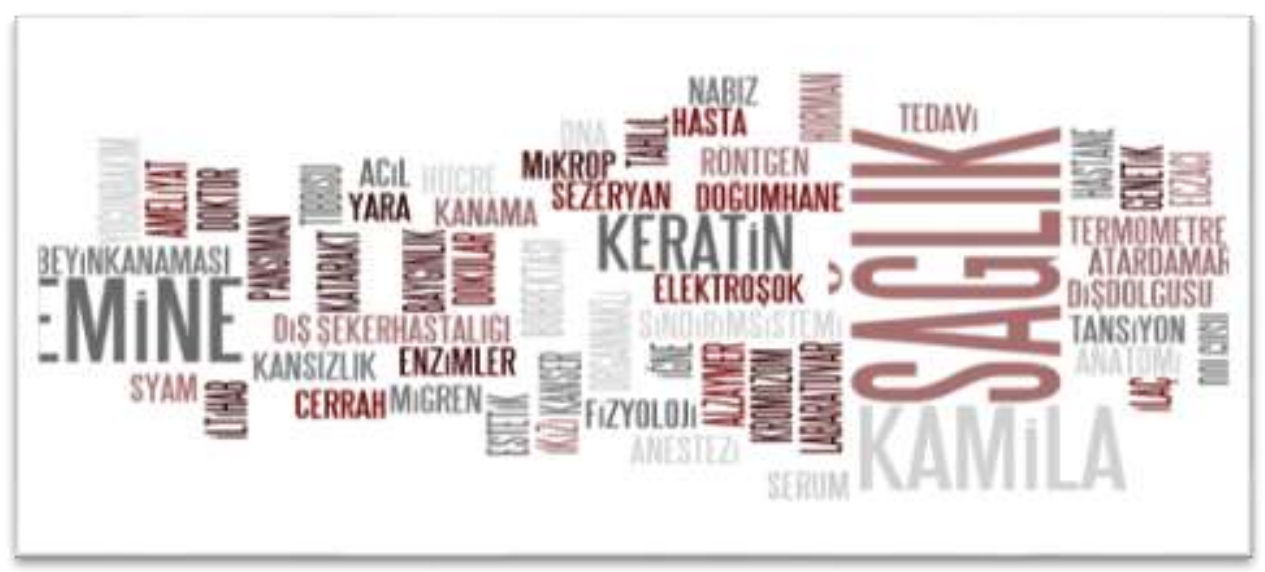

Illustration 3. An image of the term trays prepared with appropriate computer programs and shared by the students on the Facebook page.

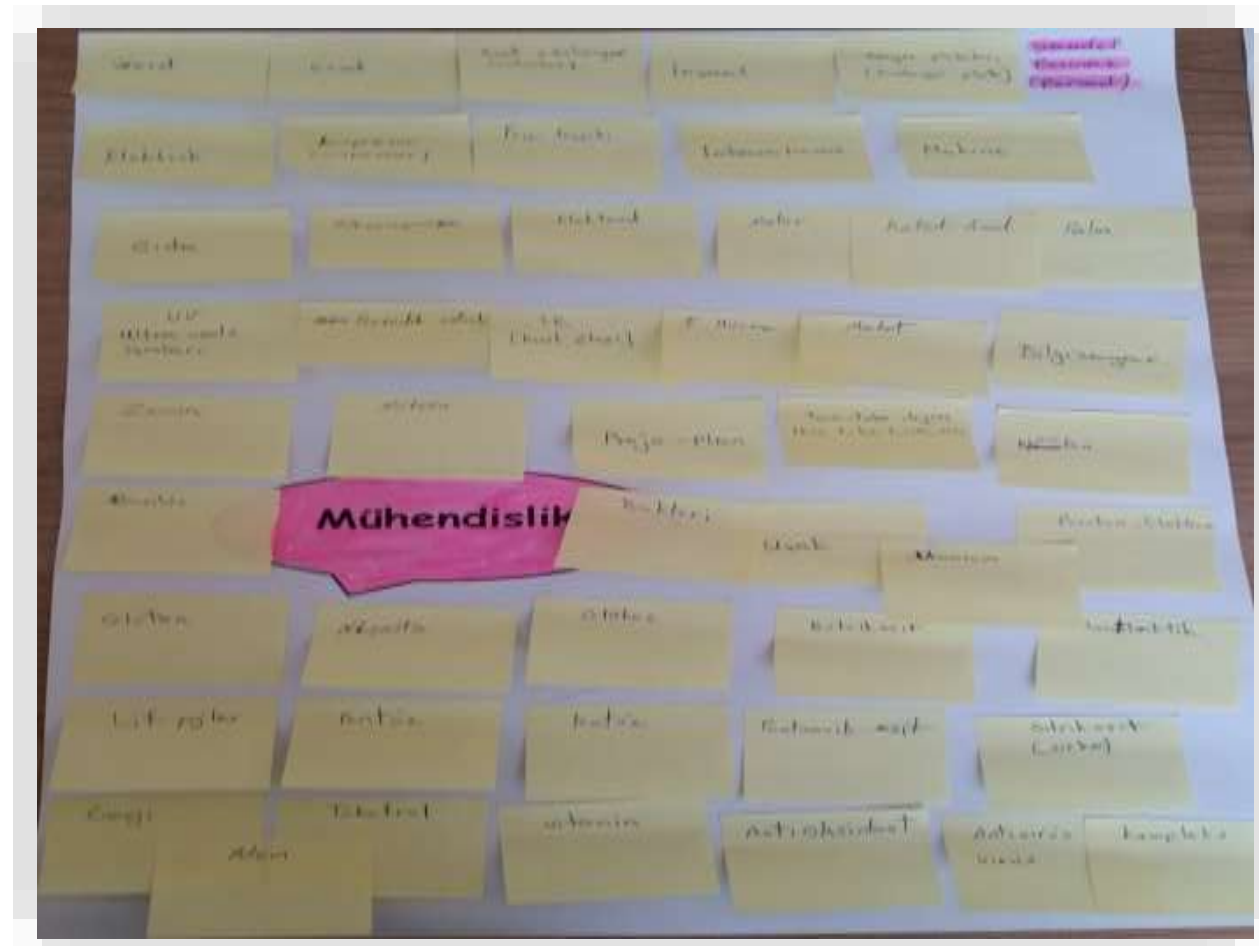

Illustration 4. An image of an idea tray 


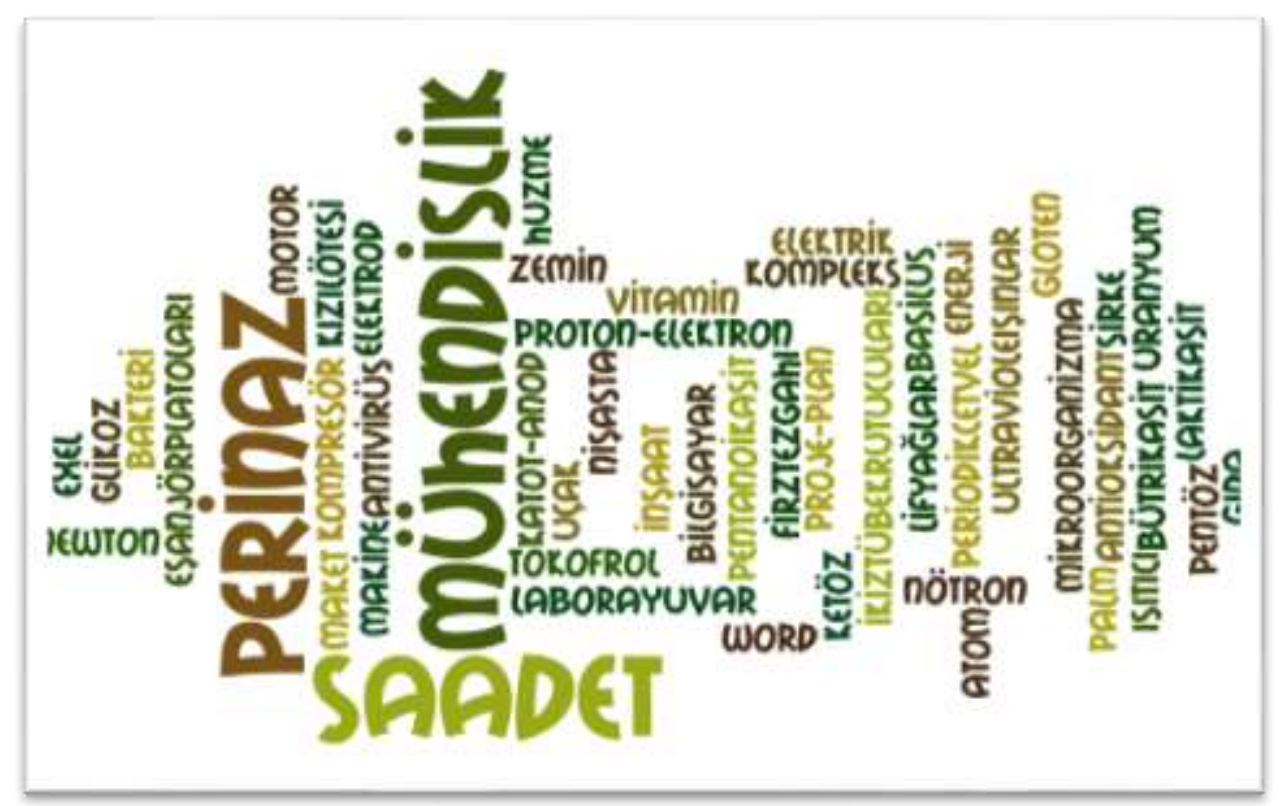

Illustration 5. An image of the term trays prepared by the students with appropriate computer programs and shared on their Facebook page.

\subsection{Listening/Watching Activity}

In this activity, students try to improve their ability to grasp and explain the new proverbs, idioms, terms and phrases they encounter in a recording they have listened to or watched. The materials to be used in the activity are as follows: Videos or recordings in which Turkish language has been correctly used, the speech and expression are intensive; a Listening/Watching Activity Self-Evaluation Form for the grouped learners to use in the aftermath of the activity, suitable sound system for sound, projection device and screen or television for image.

Table 1. Listening/Watching Activity Self-Evaluation Form

\begin{tabular}{|l|}
\hline Name / Surname: \\
\hline Name of the Movie: \\
\hline Plot of the Movie: \\
\hline New information encountered in the movie: \\
\hline New vocabulary: \\
\hline A short summary of the movie: \\
\hline New expressions learned from the movie: \\
\hline
\end{tabular}

\subsubsection{Pre-Task Stage}

The appropriate media should be prepared by the teacher before the task. In the classroom, prior to the lesson, the media should be set up and opened. The teacher should play until the scene in which the name of the media appears and pause it so that the students can read it. As for the tape recordings, the learners should listen till the part where the name of the subject comes up. Afterwards, the teacher should ask the learners to predict the subject from the name of the media and have them make a 2 to 10 minutepreparatory work about the terms they are familiar with related to the subject. The teacher should also inform the students about the form that needs to be filled after the task. 


\subsubsection{Task Cycle Stage}

In this stage, the media should be played and the learners should be asked to follow rigorously. The teacher may request them to write down the unknown vocabulary during watching or listening stages for the purpose of easing the form-filling stage to come afterwards.

\subsubsection{Presentation Stage}

In this stage, the learners should be asked to fill the Listening/Watching Activity Self-Evaluation Form. After that, they are divided into groups of three or four. Each group member is expected to combine the terms on their sheet, discuss the meanings and finally select a secretary from within the group. The secretary writes down all the terms the group have found on a blank sheet. A spokesperson is selected from within the group and tells the terms they have come up with. In the meantime, the teacher writes these terms on the board. After all groups have completed their presentations, all the learners and the teacher discuss on the meaning of the concepts written on the board and the meanings are written besides the terms. In this activity, students' listening, perceiving, explaining and speaking skills are improved.

\subsection{Story Completion Activity}

In this activity, students are asked to complete a half story with their own sentences using specific phrases. In this way, they will acquire proficiency in writing a fictional text with the target language they have learned and using the concepts, phrases and terms having taught before in the sentence. The activity should be given as homework to perform outside the classroom. Materials to be used in this activity are as follows: introduction part of a story that is convenient to continue, a list of the proverbs, idioms, concepts and phrases having taught before.

\subsubsection{Pre-Task Stage}

The teacher, in this stage, should ask questions on the concept of "story". After elaborating on the story concept, short stories which stimulate the learners' imagination should be told and they should be asked to tell similar stories, as well. Then, the sheet with the introduction part of the story and the list of the concepts required to be used should be distributed. Students could also be advised to communicate with people, to observe them and to narrate these experiences in their stories.

\subsubsection{Task-Cycle Stage}

In this process, the teacher could communicate with the learners through social networks; motivate them to write stories or answer the questions of students about the subject, if any.

\subsubsection{Presentation Stage}

The learners are asked to read their story to the class. The teacher should have all the learners listen to the story very carefully, discuss with each other about the story and ask the story writer about the new concepts they have caught. In addition, they are asked to correct the language errors they have encountered in the stories they have listened to. The teacher, in this correction process, should intervene and revise when there are any erroneous corrections.

\subsection{Listening to Turkish Folk Songs and Vocabulary Activity}

The purpose of this activity is to enable the learners to familiarize themselves with Turkish culture and traditions; to learn new proverbs, idioms and phrases. One of the significant elements of Turkish culture, the folk songs contain concepts and expressions that best reflect the Turkish culture and traditions. It is important in terms of discovering the culture itself and cultural similarities in language teaching which is a whole with culture. In this activity, it is aimed that the students will have the ability 
to do research in the target language, to understand a vocal work produced in the target language and to acquire the vocabulary of the work they have listened to.

\subsubsection{Pre-Task Stage}

The materials in this activity are computer and audio system. The teacher should have the learners listen to a piece of Turkish folk song at the beginning of the lesson and afterwards ask them if they have listened to this song before. If any, the teacher wants them to explain the lyrics and if they cannot, the teacher explains them briefly. In order to teach proverbs, idioms or specific expressions and cultural interaction, each student is asked to share at least three Turkish folk songs and their lyrics on Facebook page. They are expected to find and list the specific expressions and bring the list to the class.

\subsubsection{Task-Cycle Stage}

The learners share the songs they have found on Facebook page. The teacher likes or comments on the shares, thereby motivating them.

\subsubsection{Presentation Stage}

At this stage, the teacher brings the songs which the learners have shared on Facebook page and has the learners listen to them. Afterwards, the learner who has shared the song is asked to tell the proverbs, idioms, phrases or specific expressions in the song to the class and tries to elicit the meanings of them. In the meantime, they should pay attention to the lyrics as a whole; hence, the learners will be able to transfer their knowledge to their friends and realize an interactive learning process.

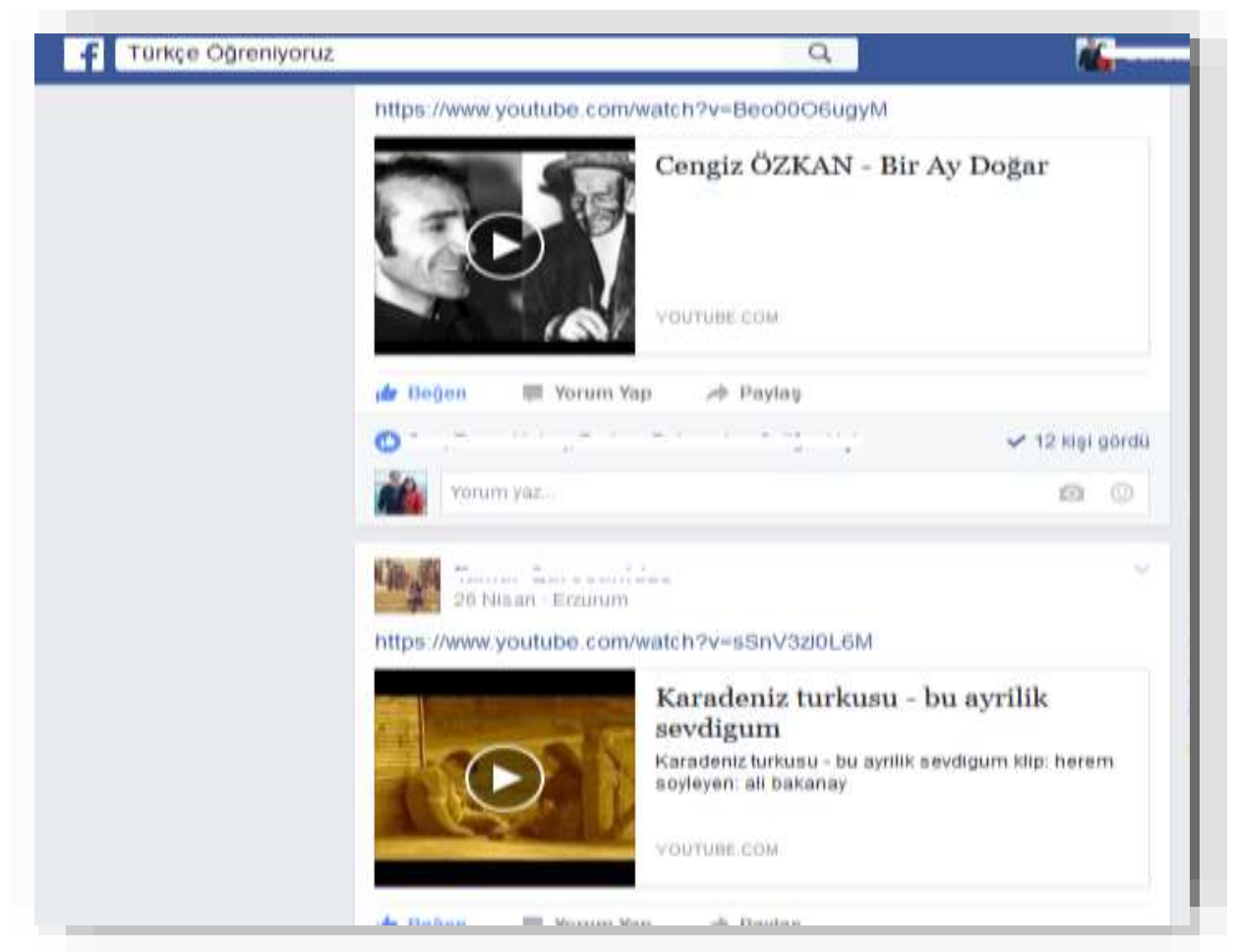

Illustration 6. A Screenshot of the Facebook page with Turkish Folk Songs prepared by the learners for the activity 


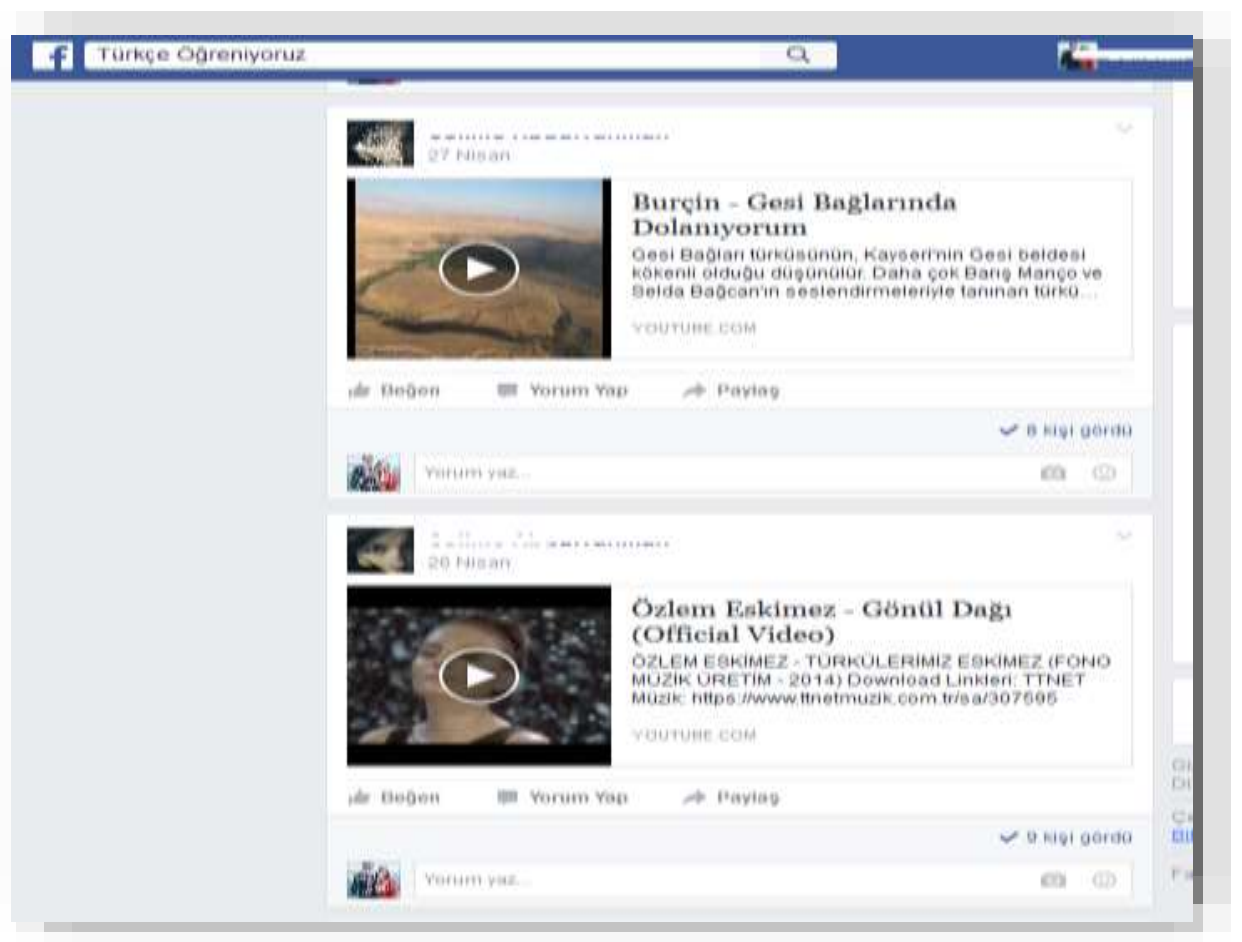

Illustration 7. A Screenshot of the Facebook page with Turkish Folk Songs prepared by the learners for the activity

\subsection{Picturing the Idiomatic Expressions or Phrases}

The purpose of this activity is to enable the learners to turn the idioms, proverbs or phrases they have learned into illustrations. By visualizing, the learners will be able to save these expressions in their photographic memory and perpetuate them. Proverbs, idioms or phrases that bear metaphorical meanings are known to be the most difficult elements to learn in a foreign language. However, the method commonly used in teaching these language elements is to transform these expressions into images or to visualize by drawing a caricature. In this activity, the students are to visualize the expressions they have learned through illustrations or caricatures. The materials to be used in this activity are a list of proverbs, idioms or phrases with their meanings prepared by the teacher, blank sheets for the illustrations.

\subsubsection{Pre-Task Stage}

In this stage, the teacher demonstrates the visuals of various idioms prepared in advance in the class. After the demonstration, the learners are asked to review these visuals and pay attention to how each idiom has been pictured. Then, the teacher gives them the lists of proverbs, idioms or phrases with their meanings prepared in advance; divides the learners into groups of two and asks them to discuss with one another and learn the meanings of the expressions in the list. The teacher distributes each learner a blank sheet thereafter and asks them to draw a picture or caricature for an expression they have chosen from the list and also spurs them on to the activity.

\subsubsection{Task-Cycle Stage}

In this stage, the teacher leaves the students alone with their own imagination. He/she ensures that the learners are comfortable and confident in drawing their pictures and willing to participate in the activity by using motivating sentences. 


\subsubsection{Presentation Stage}

The teacher collects and distributes the caricatures and illustrations of the learners to others in the class. Each learner is given the right to speak about the illustration they have and asked to predict which expression it depicts. In this way, the learner tries to understand and express a Turkish expression from his/her friend's imagination. They are asked to maintain this process in turns. Unless the depicted expression can be predicted, the owner of the illustration is asked to recount the expression in the illustration by making a story out of it. Other learners try to predict it once again. In this activity, the learners try to teach the expression to the others by drawing or reciting them, thereby making learning process mutual by interacting with one another.

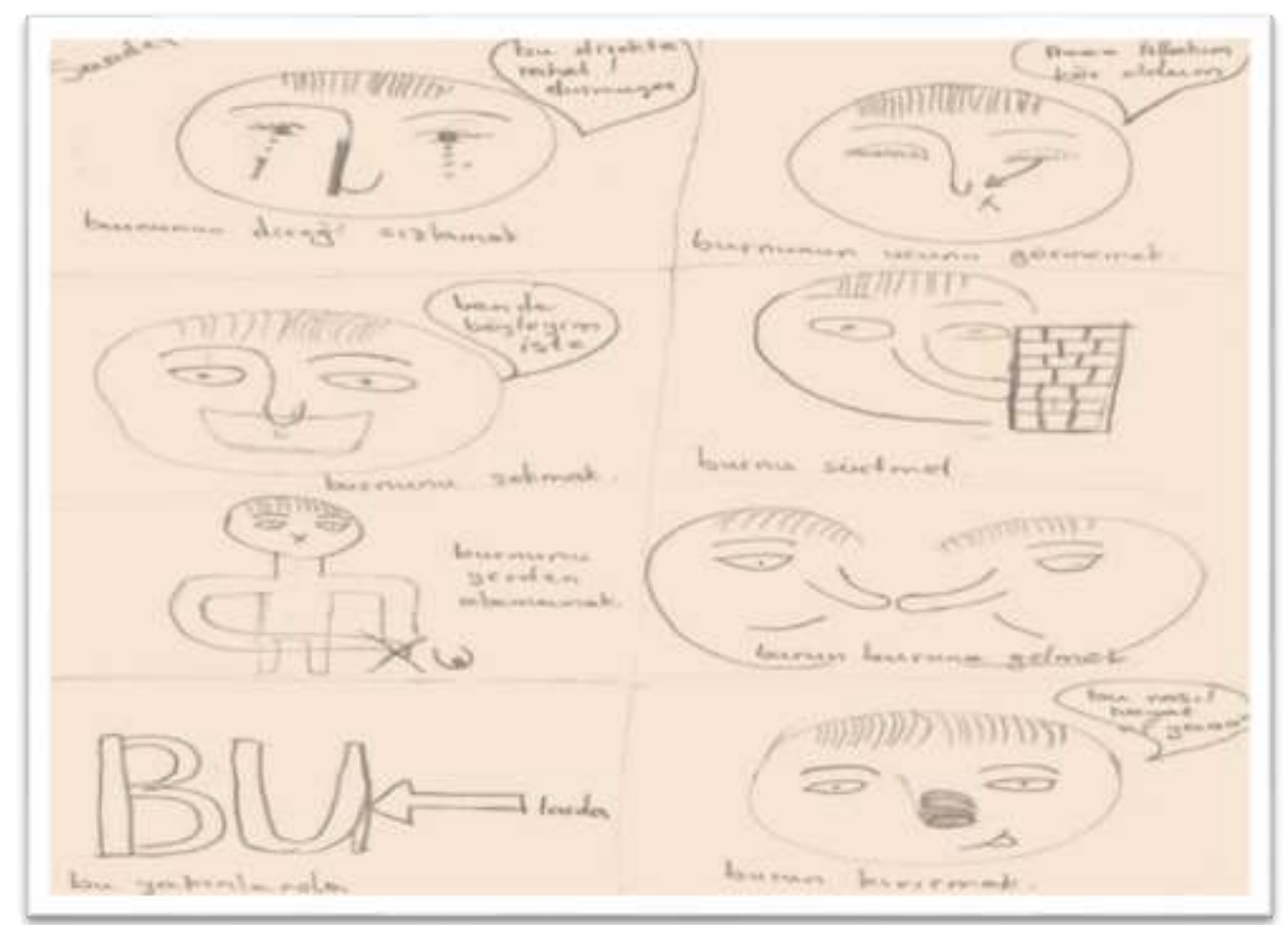

Illustration 8. The Drawings of the Learners for Picturing the Idiomatic Expressions or Phrases Activity 


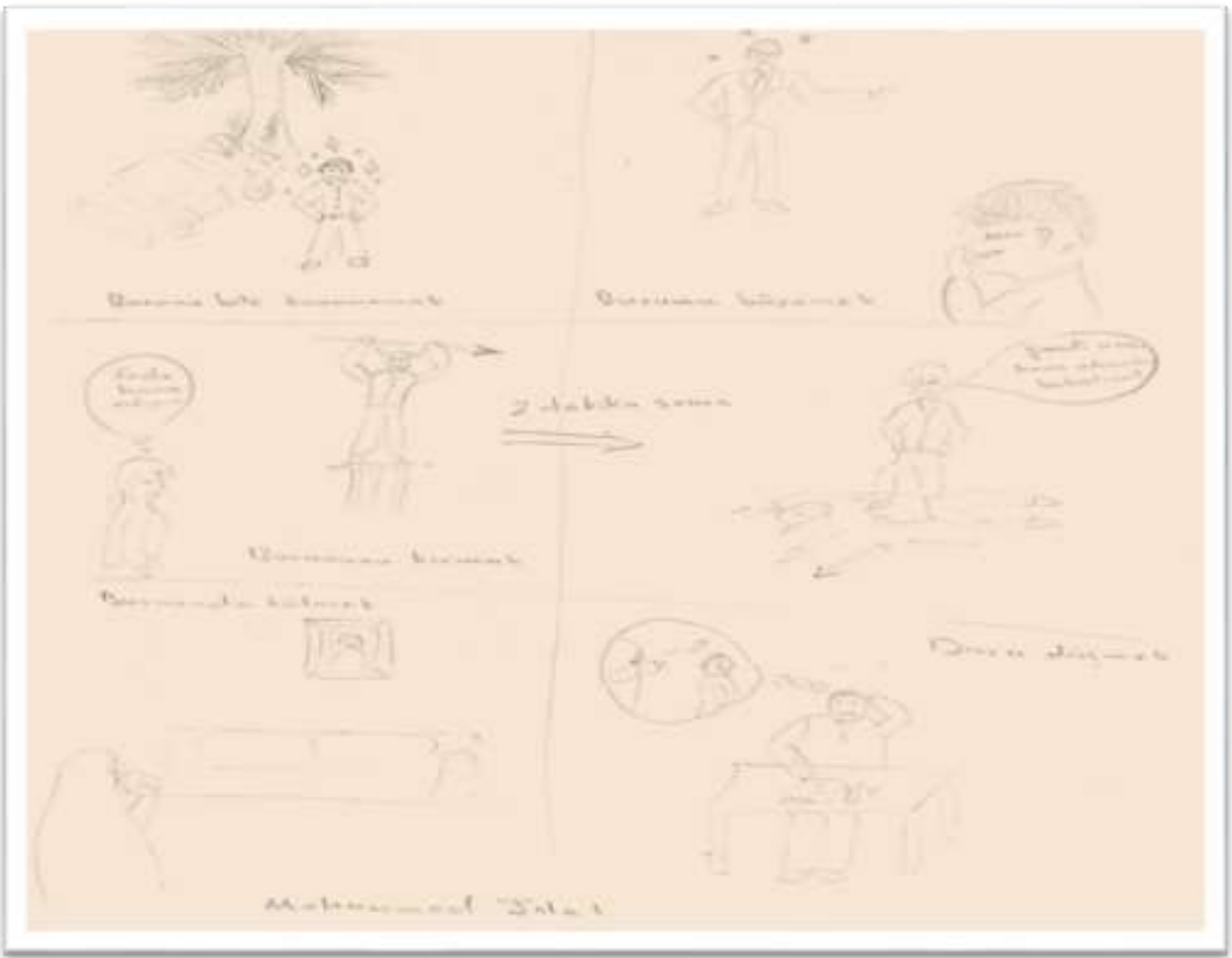

Illustration 9. The Drawings of the Learners for Picturing the Idiomatic Expressions or Phrases Activity

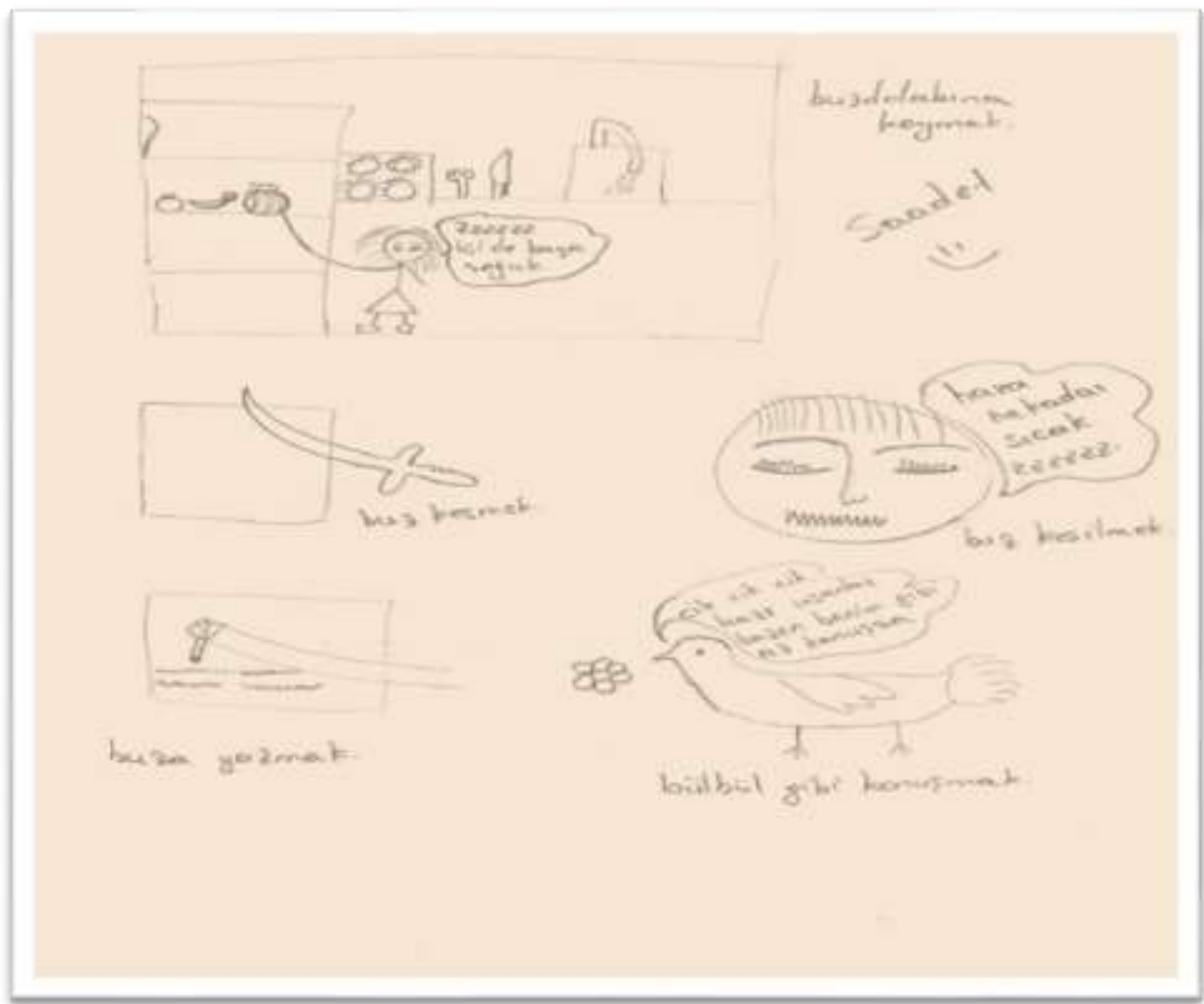

Illustration 10. The Drawings of the Learners for Picturing the Idiomatic Expressions or Phrases Activity 


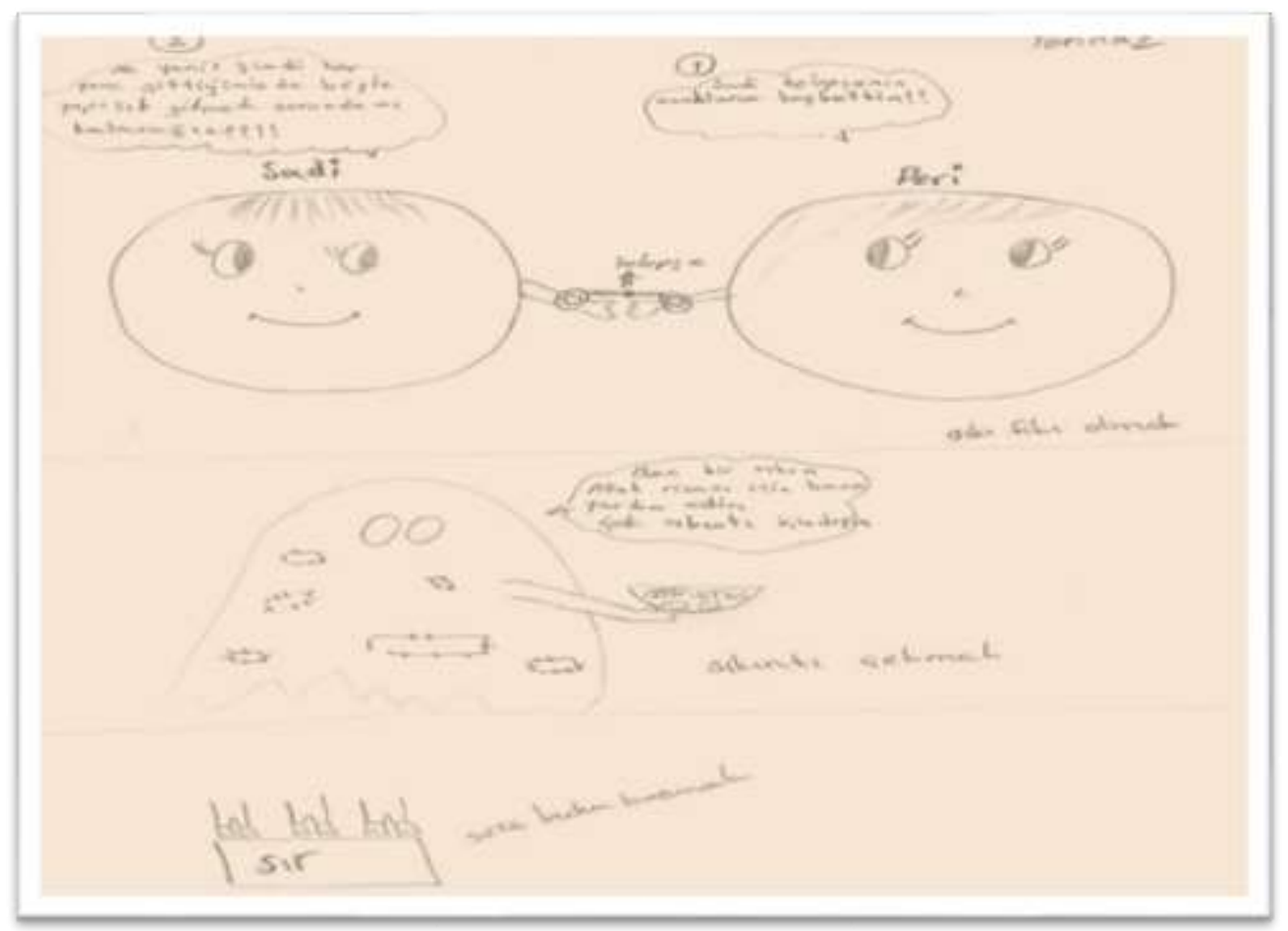

Illustration 11. The Drawings of the Learners for Picturing the Idiomatic Expressions or Phrases Activity

\subsection{Joining a Fragmented Text Together and Narrating it to the Other Groups}

The purpose of this activity is to enable the learners to join the parts of a fragmented text together in their own group and narrate it to other groups, by means of which they will improve their understanding of what they have read and their ability of combining and then narrating a text. Basically aiming to improve the skills of reading and comprehending, this activity also serves to the purposes of performing group work and conveying information among friends. Additionally, it enables the learners to go from the part to whole and to elevate their level to that of their group. The material needed for the activity is copies of a fragmented text prepared by the teacher and divided up in accordance with the number of students in each group. (Every group will have a different story and each story should be divided regarding the number of learners in a group.)

\subsubsection{Pre-Task Stage}

In this stage, the teacher informs the learners about the concept of "story" and explains the elements of the story such as context, setting, characters and the fiction. Then, the teacher creates small story drafts with the learners. In this way, the learners will be able to understand the structural parts of the story and fictionalise it. Afterwards, the teacher distributes different stories to each group. Before this distribution, the teacher must have separated each story from the appropriate place according to the number of learners in the group. The parts that make up the story should be distributed to the students randomly.

\subsubsection{Task-Cycle Stage}

First of all, each member of the groups are expected to read their own fragment without interacting with one another. While reading, they are asked to note down the unknown vocabulary and after reading, they are to find the meanings either from the teacher or a dictionary. They are also asked to take notes of the important parts in their own fragments so that they have a full understanding of the story. 


\subsubsection{Presentation Stage}

After reading is completed, the group members are asked to select a secretary and a spokesperson, who will tell the story to other groups afterwards, from within the group. Everyone tells their own part to their own group members in turns. The group members try to join the fragments into a proper story line together. The secretary writes the sequenced story line briefly and lucidly. Later, they read the whole story again and the necessary corrections are made, if any. After this process is completed in all the groups, the spokesperson of each group starts to narrate the story to other groups with the help of what the secretary has written and what he/she recalls. Meanwhile, the teacher checks if the story is united correctly. With this activity, it is aimed that the learners improve their ability to join a fragmented story together after reading and listening to a Turkish text.

\subsection{Creating a Puzzle with Terms in the Learners' Field of Education}

The purpose of this activity is to enable the learners to acquaint themselves with the terms or phrases related to the fields they are studying by using them in a puzzle. Also, by means of this activity, the learners will learn how to prepare a puzzle. Puzzles are frequently used materials in language teaching as a suitable tool for vocabulary teaching. With the puzzles prepared in accordance with each level, learners are provided with a suitable and entertaining learning activity. The material needed for this activity: A paper prepared by the teacher, with squares on which students can easily draw the puzzle squares, a white paper where the puzzle questions will be written, and coloured pencils to make the puzzle squares more visible.

\subsubsection{Pre-Task Stage}

In this stage, the teacher brings a similar puzzle to the one the learners are supposed to prepare in the class. Showing the puzzle in the classroom, the teacher asks the learners to predict and explain what it is and gives further information about puzzles according to the answers from the students. Later, he/she asks whether they like solving puzzles and why they like or dislike them, which initiates speaking in the classroom. After this preparation stage, the teacher explains the task, divides the class into groups of two and distributes the materials. The task is clearly described and the learners are asked to prepare a puzzle that is similar to the one shown before.

\subsubsection{Task-Cycle Stage}

The learners begin to create the puzzles in the areas they themselves have designated. The teacher motivates them and responds to the questions or helps in line with the questions, should the need be.

\subsubsection{Presentation Stage}

After they have completed creating the puzzles, the teacher collects and distributes each of them randomly. The learners are asked to solve the puzzle, by means of which the solubility of the puzzles and the suitability of the questions asked are controlled by the learners. After they have completed the solving process, the terms and phrases that cannot be found are asked to the other learners in the classroom, except the creators. If the missing parts can still not be predicted, the creators of the puzzle are expected to give a clue and have them guess the phrase. With this activity, the learners can improve themselves in the capability to learn the terms, form questions to verbalise them simply and understandably, create and solve a puzzle in Turkish.

\section{Conclusion}

For thousands of years, different methods have been used to learn another language. In every period, the methods which are shaped according to the needs of the people essentially aim at implementing the 
act of language teaching. Today, there are a plethora of different methods and applications in language teaching. All these methods and applications intend to accelerate and simplify the language teaching as well as making it fruitful. One of these methods, the task based language teaching (TBT), which is still developing and shaping, has emerged in the last thirty years.

Communicating is a fundamental fact of human cultures, and learning to communicate - learning to use language to do things - in another language offers considerable value from instrumental, aesthetic, moral, cognitive, and other perspectives. A basic question that must be answered by all language educators, then, is "what do our learners learn how to do, and how do they learn to do it"? Task offers a helpful way of encapsulating the things humans tend to do with language, in particular because it emphasizes the functional sense of language use (Norris, 2009). With the purpose of teaching Turkish terms and phrases in mind, TBLT method steered the learners into communication in the learning process and facilitated as well as required the interactive learning while acquiring the new terms. The functional sense of language use was invigorated thorough the designed activities as they involve interaction among the peers in the course.

Language, which is a living entity, expresses the feelings and thoughts with metaphors and similes, which makes them a semantic stratum requiring the learners of a second language to learn. These semantic stratums are language properties that are expected to be learned especially in the level of $\mathrm{C} 1$, which is defined as the level of an independent user. In this regard, the purpose of this study is to teach learners the Turkish phrases, which is a subject that is hard to learn, requires more expertise and language experience, by making use of the TBLT method for Turkish learners. With the methods designed in accordance with TBLT which includes tasks and puts peer education and learning by doing in center, learners learning Turkish as a second language can be taught Turkish phrases. In this sense, the activities designed were implemented on $\mathrm{C} 1$ level international learners in Turkish preparatory class at Ataturk University and the design of the activities were shaped assessing their observations and the feedback they gave.

Prior to the implementation of the activities, it was observed that the learners had no information about task-based language teaching method as a result of the discussions and observations we made Furthermore, we realized that they tended to memorize the idioms, proverbs, terms or phrases more; but did not try to learn within the context, the method of which they were using, and the process. In consequence with the implementation of designed activities, it was observed that with the activities, they could learn the new vocabulary through visual, auditory means as well as interaction both from each other and through deduction, which ensured that the learning was permanent and quick.

Following the activities implemented, it was concluded that the learners were informed of task-based language teaching method, the activities were more effective in the teaching of proverbs, idioms, terms and phrases and that learning was permanent. Hence, it was seen by experience that the designed activities could be utilized in the teaching of phrases. Peer education is also known to be effective in language learning. Selecting the learners in each group from common fields and interests ensured the interactive learning and learning by doing, which constitutes the basis of TBT.

As Norris states; "Ultimately, drawing on several decades of discussion and research, TBLT emerged as much more than a language teaching 'method', fun communicative techniques, or the kinds of clever activities that good teachers have always done. At its most complete, TBLT applies available understandings and evidence to the comprehensive design of entire language education programs." (Norris, 2009, p. 581) Therefore, this study is intended to be an exemplary practice in language teaching process for teachers, teaching Turkish to foreign learners who want to use TBT, which is not applied frequently in Turkey while teaching Turkish to foreigners, as well as guide them by providing model implementations. 


\section{References}

Altaş, S. (2009). Türkçe dil bilgisi ögrretiminin tarihi ve içerik odaklı dil bilgisi ögrretimi ile görev odaklı dil bilgisi öğretiminin uygulamalı karşılaştırılması (Yayımlanmamış yüksek lisans tezi), Konya: Selçuk Üniversitesi Sosyal Bilimler Enstitüsü,

Arslany1lmaz, A. (2014). Task-based language learning and teaching with technology, İstanbul: Equinox Publishing Ltd.

Balsells A. S. (2005). Review: Task-based language learning and teaching, ELT Journal, 59(1), pp. 75-77. doi:10.1093/elt/cci012.

Block, D. (2004). Review of rod ellis's task-based language learning and teaching, The Language Learning Journal, 29 (1), pp. 18-22. doi:10.1080/09571730485200051.

Büyükkarcı K. (2009). A Critical analysis of task-based learning, Kastamonu Eğitim Dergisi, 17(1), ss. 313-320.

Cebeci, N. (2006). The effectivity of task-based activities on vocabulary competence designed in accordance with the common european framework, (Yayımlanmamış Yüksek Lisans Tezi), Edirne: Trakya Üniversitesi Sosyal Bilimler Enstitüsü.

Doğan, C. (2012). Sistematik yabancı dil öğretimi yaklaşımı ve yöntemleri, İstanbul: Ensar Yayınları.

Ellis, R. (2003). Task-based language learning and teaching, Oxford, UK: Oxford University Press.

Foster, P. (1999). Task-Based learning an pedagogy, ELT Journel, 53:60-70, doi: 10.1093/elt/53.1.69.

Fotos, S. \& Ellis, R. (1999). 'Communicating about grammar: A task-based approach', in R. Ellis (Eds.), Learning a Second Language through Interaction, Amsterdam: John Benjamins Publishing Company.

Güneş, H. (2015). Eğitim bilimleri terimleri sözlüğü, İstanbul: Ütopya Yayınları.

Göçer, A. (2017). Görev temelli dil öğretim yönteminin Türkçenin ikinci dil olarak öğretiminde kullanımı, özellikleri ve işlevi, International Journal of Language Academy Volume 5/2, pp. $313 / 328$.

Koçyiğit, S. (2011). Otantik görev odakl yapılandırmacı yaklaşımın öğretmen adaylarının başarılarına, derse karşı tutumlarına ve problem çözme becerilerine etkisi (yayımlanmamış doktora tezi), İstanbul: Marmara Üniversitesi Eğitim Bilimleri Enstitüsü.

Murphy, J. (2003). 'Task-based learning: the interaction between tasks and learners', ELT Journal, Vol: 57(4), pp. 352-360.

Norris, J., M. (2009), Task-based teaching and testing. in: Michael H. Long \& Catherine J. Doughty, eds. The handbook of language teaching. Hong Kong: Blackwell Publishing.

Nunan, D. (2004). Task based language teaching, Cambridge, UK: Cambridge University Press.

Richards, J. C., \& Rodgers, T. S., (1986). Approaches and methods in language teaching, Cambridge, UK: Cambridge University Press.

Selim, İ. (2015). Görev odaklı dil ögretimi ile arapça dil bilgisi öğretimi (yayımlanmamış yüksek lisans tezi), Ankara: Gazi Üniversitesi Eğitim Bilimleri Enstitüsü.

Türkçe Sözlük, (haz.: Şükrü Haluk Akalın... [ve başk.]), (2011). -11. bsk.- Ankara: TDK.

Tütüniş, B. (1997). Task-based elt syllabus and its impact on acquisition and learning, Dil Dergisi, Say1: 51, pp. 21-25.

Willis, D., \& Willis J, (2007). Doing task-based teaching, Oxford, UK: Oxford Universty Press,

Willis, J. (1996). A flexible framework for task-based learning in: J. Willis \& D. Willis, eds. challange and change in language teaching, Oxford, UK: MacMillan Publishers Limited. 
Yayl1, D. (2006). 'The effects of task-based learning on male and female learners' proficiency and noticing, Ç.Ü. Sosyal Bilimler Enstitüsü Dergisi, Sayı: 15(1), 449-468.

Yaylı, D. (2004). Göreve dayalı öğrenme yönteminin Türkçenin yabancı dil olarak ögrretiminde uygulanması ve bu uygulamaya ilişkin öğrenci görüşleri, (Yayımlanmamış doktora tezi), İzmir: Dokuz Eylül Üniversitesi Eğitim Bilimleri Enstitüsü.

Yorulmaz, M. (2009). Göreve dayalı öğretim yönteminin Türkçenin yabancı dil olarak öğretiminde dinleme becerisinde kullanılmasının avantajları, (Yayımlanmamış yüksek lisans tezi), Edirne: Trakya üniversitesi Sosyal Bilimler Enstitüsü.

\section{Yabanci dil olarak Türkçe öğrenen öğrencilere, terim ve kalıplaşmış ifadelerin öğretiminde göreve dayalı dil öğrenme yönteminin kullanımı ve örnek etkinlik tasarım1}

\section{$\ddot{O} \mathbf{z}$}

İnsanlar farklı dillerle ve kültürle karşılaştıkları ilk anlardan beri, o dili ve kültürü öğrenme arzusundadır. Günümüz modern toplumlarında bu arzu gereklilik hâline dönüşmüştür. Bu gereklilik neticesinde arz talep dengesi değişmiş ve dünya nüfusuna paralel olarak dil öğrenme ve yeni kültürlerle tanışma artmıştır. Bu durum da dil öğretiminin ve öğreniminin bilimsel bir disiplin hâlinde gerçekleştirilmesini zorunlu kılmıştır. Dil öğretim ve öğrenim sürecinde birçok farklı yöntem ortaya çıkmış ve bilimsel veriler çerçevesinde şekillenmiştir. Bu yöntemlerden biri de göreve dayalı dil öğretim yöntemidir. Göreve dayalı dil öğretim yöntemi 20. yy.ın son çeyreğinde ortaya çıkmıştır ve günümüzde yaygın olarak dil öğretim süreçlerinde kullanılmaktadır.

$\mathrm{Bu}$ çalışmada, C1 seviyesindeki yabancı dil olarak Türkçe öğrenen öğrencilere göreve dayalı dil öğretim yönteminin dil öğretim tasarımına göre oluşturulmuş görev merkezli etkinliklerle terim ve kalıp ifadeler öğretilmeye çalışılmıştır. Terim ve kalıp ifadeler özellikle $\mathrm{C} 1$ seviyesindeki öğrencilerin dilin dört temel becerisinde bağımsız bir kullanıcı olabilmeleri için gereklidir.

Çalışma iki ana bölümden oluşmaktadır. İlk bölümde, göreve dayalı dil öğretim yöntemi hakkında literatür taraması ve genel bilgiler sunulmaktadır. İkinci bölümde ise göreve dayalı dil öğretim yönteminin öğretim tasarımına göre oluşturulmuş yedi örnek etkinlik bulunmaktadır. Bu etkinliklerde terim ve kalıp ifadeler öğrencilere görevler çevresinde öğretilmeye çalışılmıştır.

Anahtar sözcükler: yabancı dil olarak Türkçe öğretimi, göreve dayalı dil öğretimi, terim, kalıp ifadeler, etkinlik tasarımı.

\section{AUTHOR BIODATA}

Bahattin ŞIMSSEK is currently working as a lecturer at the Turkish Education Research and Application Center (TÖMER) at Ataturk University, Turkey.

Dr. Siddık Bakır is an Assistant Professor in the Ataturk University, Kazım Karabekir Faculty of Education, Division of Social Sciences and Turkish Language Education, Department of Turkish Language Education, Turkey. 